\title{
EFFECTS OF ANTI-MITOTIC AGENTS ON POLAR- BODY FORMATION AND FIRST CLEAVAGE OF HAMSTER OVA
}

\author{
M. A. BRAY* AND J. L. HANCOCK \\ Department of Anatomy, Royal Veterinary College, London NW1 OTU
}

(Received 22nd March 1972)

\begin{abstract}
Summary. The effects of two anti-mitotic agents (colchicine and vinblastine sulphate) on polar-body formation and first cleavage were examined in hamsters treated at varying intervals relative to ovulation. Colchicine failed to suppress either polar-body formation or first cleavage. Vinblastine sulphate suppressed first cleavage but had no effect on polar-body formation.
\end{abstract}

\section{INTRODUCTION}

The experiments recorded here were originally undertaken in an attempt to set up in hamsters a model for the study of embryonic death. In these experiments, the effects of the administration of two anti-mitotic agents (colchicine and vinblastine) on polar-body formation and on first cleavage were examined. The results of the experiments described here provide evidence that neither agent will effectively suppress polar-body formation. Vinblastine sulphate effectively suppressed first cleavage but no effect of colchicine on first cleavage could be demonstrated at dosages up to $50 \mu \mathrm{g} / \mathrm{g}$ body weight.

\section{MATERIALS AND METHODS}

The animals were maintained in two separate colonies under different conditions of controlled artificial lighting so that ovulation occurred at different prescribed times.

One ('daylight') colony received artificial lighting from 06.00 to 18.00 hours. Ovulation is assumed to occur under these conditions between 01.00 and 03.00 hours (Austin, 1955). The second ('dark') colony received artificial lighting from 14.00 to 04.00 hours. The time of ovulation in this colony was determined by examination at autopsy at varying intervals between 08.30 and 11.30 hours and was found to occur between 09.00 and 11.00 hours (Table 1).

Virgin female hamsters, not less than 8 weeks old, were used throughout and were mated to fertile males caged with them on the night of expected oestrus. The stage of the cycle was judged from daily visual examination of the characteristics of vaginal secretions (Orsini, 1946). The presence of spermatozoa

\footnotetext{
* Present address: W.P.U. No. 2, Haile Sellassie I University, P.O. Box 1176, Addis Ababa, Ethiopia.
} 
in vaginal smears made on the morning after mating was taken as evidence of mating.

Colchicine (BDH) for injection was dissolved in $0.9 \%$ sodium chloride. Vinblastine sulphate (Velbe-Lilley) was dissolved in $0.9 \%$ sodium chloride with added phenol $(0 \cdot 5 \%)$ as a preservative; solutions were prepared on the day of use.

Tubal ova were recovered at autopsy by flushing the excised oviducts through the infundibulum. The ova were mounted whole by the method of Chang (1952), fixed for 1 to $2 \mathrm{hr}$ or overnight in buffered formal saline, cleared in Carnoy's fixative (ethyl alcohol, chloroform, glacial acetic acid; $6: 3: 1$, by vol.) and stained in acetic lacmoid for $20 \mathrm{~min}$. The preparations were examined by phase-contrast microscopy for evidence of fertilization after replacement of the stain by $45 \%$ acetic acid. The accepted criteria of normal fertilization were the

Table 1. The distribution of 'dark'-colony hamsters (see text) according to the stage of ovulation recorded at autopsy at varying times of the day

\begin{tabular}{|c|c|c|c|c|c|c|c|}
\hline \multirow[b]{2}{*}{ Ovulation } & \multicolumn{7}{|c|}{ Time of autopsy } \\
\hline & 08.30 & 09.00 & 09.30 & 10.00 & 10.30 & 11.00 & 11.30 \\
\hline$\overline{ \pm}$ & 1 & $\begin{array}{l}3 \\
4\end{array}$ & $\begin{array}{r}11 \\
14 \\
2\end{array}$ & $\begin{array}{r}7 \\
12 \\
5\end{array}$ & $\begin{array}{r}2 \\
5 \\
11\end{array}$ & $\begin{array}{r}0 \\
3 \\
32\end{array}$ & $\begin{array}{r}0 \\
2 \\
22\end{array}$ \\
\hline
\end{tabular}

- , Ovulation not begun; \pm , ovulation begun but incomplete; + , ovulation complete.

presence of a single spermatozoon with either resumption or completion of the second meiotic division or the presence of two pronuclei and of two polar bodies.

Counts of implanted embryos were made at autopsy 10 days after mating. (In this paper, the day of onset of oestrus is referred to as Day 0; Day 1 is the day of ovulation, i.e. the first day of metoestrus).

\section{RESULTS}

The effect of colchicine given intraperitoneally or subcutaneously was examined in hamsters treated at varying times after ovulation. A factorial $3 \times 3 \times 2$ design was used, the variables being: dose of colchicine $(5.0 \mu \mathrm{g}, 50.0 \mu \mathrm{g}$ or none $) / \mathrm{g}$ body weight, time of administration relative to ovulation $(0 \mathrm{hr}, 3 \mathrm{hr}$ or $6 \mathrm{hr}$ after ovulation) and route of administration (intraperitoneal or subcutaneous). For this purpose, treated animals from the 'dark' colony received either $0.5 \mathrm{mg}$ or $5.0 \mathrm{mg}$ at $09.00,12.00$ or 15.00 hours; control, untreated animals received injections of saline at the same times. Control and treated animals were examined at autopsy at 17.00 hours. Pairs of hamsters were allocated at random to the six treatment groups.

The results are summarized in Table 2 . There is little evidence of any effect of treatment. A total of six fertilized eggs with abnormal features were recovered 
from treated animals. Two of these were clearly dispermic and the rest had three pronuclei and two polar bodies and could also have been dispermic.

The evidence here is clearly against the existence of any ability of colchicine to suppress polar-body formation. There was no evidence of any effect of any of the variables. Of the six abnormal ova, two were from animals treated subcutaneously with $50 \mu \mathrm{g} / \mathrm{g}$ body weight; one of these was from an animal injected at the time of ovulation and the other from an animal injected $6 \mathrm{hr}$

Table 2. The effects on fertilization and polarbody formation of varying doses of colchicine given subcutaneously or intraperitoneally at $0 \mathrm{hr}, 3 \mathrm{hr}$ or $6 \mathrm{hr}$ after ovulation in hamsters

\begin{tabular}{c|c|c|ccc}
\hline \multirow{2}{*}{$\begin{array}{c}\text { Dose } \\
(\mu \mathrm{g} / \mathrm{g}\end{array}$} & $\begin{array}{c}\text { No. of } \\
\text { body } w t)\end{array}$ & $\begin{array}{c}\text { No. of } \\
\text { ova } \\
\text { hamsters }\end{array}$ & \multicolumn{3}{|c}{ Fertilized ova } \\
\cline { 4 - 6 } & 12 & 129 & 84.5 & 107 & 2 \\
$5 \cdot 0$ & 12 & 147 & $70 \cdot 7$ & 100 & 4 \\
0.5 & 12 & 133 & 78.0 & 105 & 0 \\
0 & 12 & & & \\
\hline
\end{tabular}

after ovulation. The remaining four abnormal ova were from hamsters receiving the lower dose of colchicine, three of them being from animals injected intraperitoneally. No effect of time of treatment relative to ovulation was discernible; the abnormal ova were recovered from representatives of all three treatment groups.

In view of the failure to suppress polar-body formation by treatment with colchicine, the same experimental design was used to examine the effects of the anti-mitotic agent vinblastine which has been shown (R. W. McGaughey, personal communication) effectively to suppress first cleavage of hamster ova. Animals from the 'dark' colony were injected at two dosage levels $(1.0 \mu \mathrm{g}$ and $0.5 \mu \mathrm{g} / \mathrm{g}$ body weight).

The results which are summarized in Table 3 show that vinblastine, like colchicine, had little or no effect on polar-body formation. Ten ova from treated animals were judged to be abnormal but evidence of suppression was found in only five of a total of 223 eggs examined from vinblastine-treated animals. All

Table 3. The effects on fertilization and polar-body formation of varying doses of vinblastine sulphate given subcutaneously or intraperitoneally at varying times relative to ovulation in hamsters

\begin{tabular}{c|c|c|ccc}
\hline \multirow{2}{*}{$\begin{array}{c}\text { Dose } \\
(\mu \mathrm{g} / \mathrm{g}\end{array}$} & $\begin{array}{c}\text { No. of } \\
\text { body wt })\end{array}$ & $\begin{array}{c}\text { No. of } \\
\text { ova } \\
\text { hamsters }\end{array}$ & \multicolumn{3}{|c}{ Fecovilized ova } \\
\cline { 4 - 6 } & recoved & $\%$ & Normal & Abnormal \\
\hline 1.0 & 14 & 121 & $92 \cdot 6$ & 105 & $7 *$ \\
0.5 & 13 & 128 & 86.7 & 108 & $3 \dagger$ \\
0 & 12 & 136 & 85.3 & 115 & 1 \\
\hline
\end{tabular}

* Two with suppressed polar bodies.

$\dagger$ Three with suppressed polar bodies. 
affected ova were from animals treated at the time of ovulation or within $3 \mathrm{hr}$ of its occurrence.

A second experiment was designed to examine the possibility that vinblastine might be used to suppress formation of either the first or the second polar body. A $2 \times 4$ factorial design was used, the variables being time of injection $(0 \mathrm{hr}$ or $17 \mathrm{hr}$ before ovulation) and dosage $(0,0.5,1.0$ or $2.0 \mu \mathrm{g} / \mathrm{g}$ body weight). Treated animals from the 'dark' colony were injected intraperitoneally with $0.5 \mu \mathrm{g}, 1.0 \mu \mathrm{g}$ or $2.0 \mu \mathrm{g} / \mathrm{g}$ body weight at 09.30 hours on Day 1 (i.e. within $1 \mathrm{hr}$ of ovulation) or at 17.00 hours on Day 0 (i.e. $17 \mathrm{hr}$ before ovulation). There was evidence of some adverse effects of treatment (Table 4) in that twenty-five of a

Table 4. The effects on fertilization and polar-body formation of vinblastine sulphate injected intraperitoneally into hamsters at the time of ovulation or $17 \mathrm{hr}$ previously

\begin{tabular}{c|c|c|c|ccc}
\hline \multirow{2}{*}{$\begin{array}{c}\text { Time of } \\
\text { treatment } \\
\text { (hours before) } \\
\text { ovulation) }\end{array}$} & Treatment & $\begin{array}{c}\text { No. of } \\
\text { hamsters }\end{array}$ & $\begin{array}{c}\text { No. of } \\
\text { ova } \\
\text { recovered }\end{array}$ & \multicolumn{3}{|c}{ Fertilized ova } \\
\hline \multirow{2}{*}{17} & 13 & 101 & 9 & Normal & Abnormal \\
\cline { 2 - 6 } & Treated & 13 & 39 & 100 & 37 & 9 \\
& Untreated & 4 & 139 & 0 \\
& Treated & $13^{*}$ & 121 & 85.9 & 88 & 16 \\
& Untreated & 4 & 34 & 97.0 & 33 & 0 \\
\hline
\end{tabular}

* Two infertile matings.

total of 175 fertilized eggs were judged to be abnormal, the chief abnormalities being anomalous numbers of pronuclei, but, in no case, was there evidence of suppression of first or second polar bodies.

In a further experiment, the variables examined were time of injection ( $8 \mathrm{hr}$ or $3 \mathrm{hr}$ before ovulation) and dosage of vinblastine $(0,1.0$ or $2 \mu \mathrm{g} / \mathrm{g}$ body weight). For this purpose, animals from the 'light' colony were injected intraperitoneally at 17.00 or 22.00 hours on Day 0 and were examined at autopsy at 14.00 hours on Day 1. Of a total of 185 ova from treated hamsters, suppression of the second polar body had occurred in only two (Table 5).

Table 5. The effect on fertilization of vinblastine sulphate given intraperitoneally $3 \mathrm{hr}$ or $8 \mathrm{hr}$ before ovulation in hamsters

\begin{tabular}{c|c|c|c|ccc}
\hline $\begin{array}{c}\text { Time of } \\
\text { treatment } \\
\text { (hours before } \\
\text { ovulation) }\end{array}$ & Treatment & $\begin{array}{c}\text { No. of } \\
\text { hamsters }\end{array}$ & $\begin{array}{c}\text { No. of } \\
\text { ova } \\
\text { recovered }\end{array}$ & \multicolumn{3}{|c}{ Fertilized ova } \\
\hline \multirow{2}{*}{8} & Treated & 9 & 88 & $96 \cdot 5$ & 79 & $5 \ddagger$ \\
& Untreated & 4 & 45 & 100 & 45 & 0 \\
& Treated & $10^{*}$ & 97 & 95.9 & 87 & $5 \ddagger$ \\
& Untreated & $5 \dagger$ & 47 & $95 \cdot 7$ & 42 & 3 \\
\hline
\end{tabular}

* Two infertile matings.

† One infertile mating.

$\ddagger$ One with polar body suppressed. 
Table 6. The effects on first cleavage of vinblastine sulphate given $9 \mathrm{hr}$ after ovulation in hamsters

\begin{tabular}{c|c|c|c|ccc}
\hline $\begin{array}{c}\text { Time of } \\
\text { treatment } \\
\text { (hours after } \\
\text { ovulation) }\end{array}$ & Treatment & $\begin{array}{c}\text { No. of } \\
\text { hamsters }\end{array}$ & $\begin{array}{c}\text { No. of } \\
\text { ova } \\
\text { recovered }\end{array}$ & \multicolumn{3}{|c}{ Fertilized ova } \\
\hline 9 & Treated & 9 & 75 & 100 & One-cell & Two-cell \\
\hline 9 & Untreated & 3 & 33 & 100 & 0 & 33 \\
\hline
\end{tabular}

* Fifteen judged to be abnormal.

In view of the consistent failure in these experiments of vinblastine sulphate to suppress polar-body formation, it seemed important to confirm the ability of the agent to suppress first cleavage. In an experiment designed to do this, effects of dosage $(0,1.0$ and $2.0 \mu \mathrm{g} / \mathrm{g}$ body weight $)$ were examined in hamsters from the 'daylight' colony injected intraperitoneally approximately $9 \mathrm{hr}$ after ovulation (10.00 hours). The findings which are summarized in Table 6 provide clear evidence of the ability of vinblastine sulphate to suppress cleavage at dosage levels which are without effect on polar-body formation. Of seventy-five fertilized ova from treated females, forty-three were uncleaved and a further fifteen were judged to be abnormal.

Table 7. The effects of colchicine (given $8 \mathrm{hr}$ before ovulation) on polarbody formation and (given $9 \mathrm{hr}$ after ovulation) on first cleavage in hamsters

\begin{tabular}{c|c|c|c|ccc}
\hline \multirow{2}{*}{$\begin{array}{c}\text { Day of } \\
\text { autopsy }\end{array}$} & Treatment & $\begin{array}{c}\text { No. of } \\
\text { hamsters }\end{array}$ & $\begin{array}{c}\text { No. of } \\
\text { ova } \\
\text { recovered }\end{array}$ & \multicolumn{3}{|c}{ Fertilized ova } \\
\hline \multirow{2}{*}{1} & Treated & 4 & 41 & 97.0 & One-cell & Two-cell \\
\cline { 5 - 7 } 2 & Untreated & 4 & 37 & 100 & 37 & 0 \\
& Treated & 4 & 36 & 100 & 1 & 35 \\
& Untreated & $4^{*}$ & $43^{*}$ & 100 & 0 & 14 \\
\hline
\end{tabular}

* One hamster yielded fertilized eggs (fourteen), the other three hamsters yielded unfertilized eggs only.

In view of the observation that the meiotic and mitotic divisions were not equally affected by this particular anti-mitotic agent, the effects of colchicine on both polar-body formation and first cleavage were examined simultaneously.

Effects on polar-body formation were studied in hamsters injected at 17.00 hours on Day 0 ( $8 \mathrm{hr}$ before ovulation) and examined at autopsy at 14.00 hours on Day 1 (13 hr after ovulation). Effects on first cleavage were studied in hamsters injected at 10.00 hours on Day 1 ( $9 \mathrm{hr}$ after ovulation). Colchicine dosage was $50 \mu \mathrm{g} / \mathrm{g}$ body weight (Table 7 ).

The results show that at this dosage and under these conditions, colchicine suppresses neither polar-body formation nor first cleavage.

\section{DISCUSSION}

The effects of colchicine on the meiotic and mitotic divisions of the hamster egg are in marked contrast to those observed in other species. The successful 
use of colchicine for these purposes has been recorded in the rabbit (Pincus \& Waddington, 1939; Bomsel-Helmreich \& Thibault, 1962), rat (Austin \& Braden, 1954; Piko \& Bomsel-Helmreich, 1960) and mouse (Edwards, 1954; McGaughey \& Chang, 1969). Because of the similarities of the experimental approach, it is particularly interesting to compare the results of our experiments with those recorded by McGaughey \& Chang (1969). They showed that colchicine effectively suppressed the second meiotic division in mice receiving 0.5 to $3.0 \mu \mathrm{g} / \mathrm{g}$ body weight when this was injected $30 \mathrm{~min}$ before to $3 \frac{1}{2} \mathrm{hr}$ after ovulation; considering only eggs where the penetrating spermatozoon showed swelling of the head and an intact tail (Type III), only one of twenty-four eggs from treated mice had reached anaphase compared with twenty-six of twentyseven from untreated mice. In their experiments, colchicine had markedly adverse effects on fertilization when given less than $3 \frac{1}{2} \mathrm{hr}$ after ovulation. Our observations on the hamster show relatively little effect of colchicine on fertilization and no effect on either polar-body formation or first cleavage. The evidence here of the ineffectiveness of colchicine as an inhibitor of mitosis supports previous evidence of the resistance of hamsters to this agent. A high degree of resistance to the toxic effects of colchicine has been observed by Turbyfill \& Soderwall (1957) and by Orsini \& Pansky (1952). At the cellular level, it has been shown (Midgley, Pierce \& Dixon, 1959) that colchicine is active against human and mouse tissues transplanted into hamsters in doses which are without effect on homografts of hamster tissues. There is other evidence (Wrba, 1959, 1961) that heterografts of rat tissue to hamster become as resistant to colchicine as those of the host and that this acquired resistance of the rat tissue is maintained after regrafting back to rats.

The evidence as regards the resistance to colchicine of embryonic hamster tissue is contradictory, some workers (Midgley et al., 1959) finding evidence of a high degree of resistance and others (Ferm, 1963; Sundell, 1962), little or no evidence.

Midgley et al. (1959) found that hamster embryonic tissues were highly resistant to treatment in vitro with colchicine but there is other evidence that treatment of the mother effectively inhibits mitotic activity in blastocysts (Sundell, 1962) and $8 \frac{1}{2}$-day-old embryos (Ferm, 1963). We have no satisfactory explanation for these differences.

The observations on the effects of vinblastine suggest that there are differences in response to this agent between the mitotic and meiotic spindles. A similar difference in response to colchicine has been recorded by Roosen-Runge (1951) between mitotic (spermatogonia) and meiotic (spermatocyte) divisions in rat testis. The effectiveness of vinblastine for the suppression of first cleavage of the hamster confirms the observations of McGaughey (personal communication) and agrees with previous observations (Cardinali, Cardinali, Handler \& Agrifoglio, 1961) about the relative efficiency of colchicine and vinblastine for the suppression of mitosis in hamsters.

\section{AGKNOWLEDGMENT}

This work was supported by a grant to one of us (J.L.H.) from the Agricultural Research Council. 


\section{REFERENCES}

Austiv, C. R. (1955) Ovulation, fertilization and early cleavage in the hamster. $\mathcal{F l ~ R}$. microsc. Soc. 75, 141.

Austin, C. R. \& Braden, A. W. H. (1954) Induction and inhibition of the 2nd division in the rat egg, and subsequent fertilisation. Aust. F. biol. Sci. 7, 195.

Bomsel-Helmreich, O. \& Thibault, C. (1962) Developpement d'oeufs triploides experimentaux chez la lapine. Annls Biol. anim. Biochim. Biophys. 2,9.

Cardinali, G., Gardinali, G., Handler, A. H. \& Agrifoglio, M. F. (1961) Comparative effects of colchicine and vincaleukablastine on bone marrow mitotic activity in Syrian hamster. Proc. Soc, exp. Biol. Med. 107, 891.

Chano, M. C. (1952) Fertilisation of rabbit ova and the effects of temperature in vitro on their subsequent fertilisation and activation in vivo. J. exp. Zool. 121, 351 .

Edwards, R. G. (1954) Colchicine induction of heteroploidy in early mouse embryos. Nature, Lond. 174, 276.

Ferm, V. H. (1963) Colchicine teratogenesis in hamster embryos. Proc. Soc. exp. Biol. Med. 112, 775.

McGaughey, R. W. \& Chang, M. C. (1969) Inhibition of fertilization and production of heteroploidy in eggs of mice treated with colchicine. J. exp. Zool. 171, 465.

Midgley, A. K., Pierce, B. \& Dixon, F. J. (1959) Nature of colchicine resistance in the golden hamster. Science, N.Y. 130, 40.

ORsinI, M. W. (1946) A study of the oestrous cycle and the breeding of the golden hamster. Anat. Rec. 94, 139.

ORsini, M. W. \& PANSKy, B. (1952) The natural resistance of the golden hamster to colchicine. Science, N.r. $115,88$.

Pixo, L. \& Bomsel-Helmreich, O. (1960) Triploid rat embryos and other chromosomal deviants after colchicine treatment and polyspermy. Nature, Lond. 186, 737.

Pincus, G. \& Waddington, C. H. (1939) The effects of mitosis-inhibiting treatments of normal fertilised pre-cleavage rabbit eggs. The comparative behaviour of mammalian eggs in vivo and in vitro. 7. Hered. 30, 514 .

Roosen-Runge, E. C. (1951) Quantitative studies on spermatogenesis in the albino rat. Am. F. Anat. 88, 163.

Sundell, G. (1962) The sex ratio before uterine implantation in the golden hamster. J. Embryol, exp. Morph. 10, 58.

Turbyfill, G. L. \& Soderwall, A. L. (1957) Gross effects of colchicine on the golden hamster. Science, N.Y. 126, 749.

WRBA, H. (1959) Wachstum der heterotransplanten Mäuse-Ratten Tumoren auf unbehandelten Goldhamstern. Naturwissenschaften, 46, 339.

WRBA, H. (1961) On the colchicine resistance of heterologous growing tumours in the golden hamster. Z. Krebsforsch. 64, 88. 